\title{
Sociocultural theory and blind taste-tests
}

\author{
JAMES PAUL GEE Mary Lou Fulton Presidential Professor of Literacy Studies, \\ Arizona State University
}

In his entertaining 1986 book, The Real Coke, the Real Story, Thomas Oliver tells the story of the now infamous "New Coke", a story retold in Malcolm Gladwell's (2005) best-seller Blink. In the early 1980s, Pepsi began running commercials in which people took a sip from two glasses, not knowing which was Coke and which Pepsi. The majority preferred Pepsi. The Coca-Cola Company replicated these blind taste-tests and found the same result. Losing market share, Coke-long the dominant brand-changed its old formula and came out with "New Coke", a soda made to a new formula, one that in a new round of blind taste-tests came out above Pepsi. But New Coke was a disaster. Consumers hated it. Coke not only returned to its old formula, but Pepsi never did overtake Coke, which remains today the dominant brand world-wide.

In a sip test, tasters don't drink an entire bottle or can of soda-they just take a sip of two or more different brands. It turns out that if you ask people, not just to take a sip, but to take a case or two of each drink home for a few weeks, you often get a different result. Taking a sip of a drink and drinking a whole bottle or can are different experiences- sometimes, for example, the first sip is sweet, but the whole bottle is, by the end, cloying. Furthermore, people report their taste preferences differently when they are drinking at home, in front of their $\mathrm{TV}$, than they do when they are drinking in a lab under artificial conditions.

There's also this problem: though we do not usually think of the package something comes in as part of its taste, it turns out that people reliably say things taste better or worse based partly on how they are packaged. Gladwell (2005: pp. 160ff ) points out that people think yellow margarine tastes better than white margarine, even if they are tasting the same margarine with different colorings. People report that a given brand of brandy tastes better when they see it in a better looking bottle. This is so because people transfer impressions they have about the packaging of a product-or aspects of the context in which they use the product or with which they associate the product-to the product itself, for example, to its taste.

There is nothing "unscientific" about a sip taste-it's a nice controlled sort of study of a rather classic sort. But it is misleading, in the case of the New Coke

\footnotetext{
${ }^{1 *}$ This opinion piece and other writings on literacy and language studies can be read at the author's website. See http://jamespaulgee.com

READING AND WRITING

(C) 2010 J. Gee Vol 1, No 1, 2010, 83-84.
} 
disastrously so. To truly know people's preferences you need to know how the product is situated in, placed within, the lived social practices of the person and his or her interpretations of those practices. That is what the New Coke story has to tell us about assessing people's preferences. A sociocultural view of human language, learning, and mind takes the same view of people's talents (Gee 1992, 2004). To fairly and truly judge what a person can do you need to know how the talent (skill, knowledge) you are assessing is situated in, placed within, the lived social practices of the person and his or her interpretations of those practices. Like sip tests, many a standardized test is perfectly "scientific" and useless - and, perhaps, worse, disastrous.

The lived practices and interpretations of a person are, of course, social and cultural, but not (just) in the sense that something as big as a "culture" (e.g., "Americans", "African- Americans", "Native-Americans", "Russians", "the Chinese", etc.) has trait "X" or property "Y" for which we must adjust and adapt, though, of course, when such things are true, they are well worth adapting for. Lived practices and interpretations are social and cultural in the sense that we only understand them if and when we study them in terms of the sorts of thick descriptions of webs of signification that Clifford Geertz called for (Geertz 1973).

Say, for instance, you want to know, not whether someone can decode print, but whether he or she can read school-based ("academic") language (for instance, 8th grade science). Now you do not want to give them a sip test of reading as decoding and the assignment of rather literal meanings to texts. Rather, you want to know how such reading is or is not situated in specific ("academic") practices, forms of life, and interpretations for this person (Gee 2004). But you need to know, as well-at least if you want to be fair and justwhether this person has ever had the opportunity for such reading to become embedded in a lived practice with which he or she has become "at home". If such "academic language" is only something the person has sipped out of any real context of use, value, and meaning, but never taken home by the case, then no fair judgment of that individual's talent in this respect is available.

\section{References}

Gee, J. P. 1992. The social mind: Language, ideology, and social practice. New York: Bergin \& Garvey.

Gee, J. P. 2004. Situated language and learning: A critique of traditional schooling. London: Routledge.

Gladwell, M. 2005. Blink: The power of thinking without thinking. New York: Little, Brown. Geertz, C. 1973. The interpretations of cultures. New York: Basic Books.

Oliver, T. 1986. The real Coke, the real story. New York: Random House. 